\title{
A survey of damage observed in Izmir due to 2020 Samos-Izmir earthquake
}

\author{
Hasan Emre Demirci ${ }^{1} \cdot$ Mustafa Karaman $^{2} \cdot$ Subhamoy Bhattacharya $^{3}$ (D)
}

Received: 26 November 2020 / Accepted: 22 October 2021 / Published online: 2 November 2021

(c) The Author(s) 2021

\begin{abstract}
An earthquake of magnitude 6.9 hit the city of Izmir (Turkey) on 30 October 2020, resulting in 117 deaths (in Turkey) and considerable economic losses. The earthquake also triggered a tsunami. Following the earthquake, field surveys are being conducted in a Covidsecure way to study and document the damages caused. The earthquake caused significant damages to residential buildings mainly located in the district of Bayrakli and Bornova. However, no damages were observed in railway and roadway bridges or tunnels and that helped the rescue operations. The damages were mainly structural which included the socalled pancake collapse (where the entire building collapsed) and soft storey type collapse (weak storey characterised with weak columns collapsed), and in some cases, only the ground floor completely collapsed. Due to the proximity of the epicentre and the geology of the area, it seemed that the ground motions were amplified. This technical note provides a summary of the seismological and recorded ground characteristics of the earthquake together with the lessons learnt.
\end{abstract}

Keywords 2020 Samos-Izmir earthquake $\cdot$ Residential buildings · Damage $\cdot$ Ground amplifications

\section{Introduction}

An earthquake occurred on 30 October 2020 in the Aegean Sea, $8 \mathrm{~km}$ north of Samos Island. Kandilli Observatory and Earthquake Research Centre (Bosphorus University 2020) reported a moment magnitude $\left(M_{w}\right)$ of 6.9 while Disaster and Emergency Management Presidency, (AFAD) (AFAD 2020) reported an $\mathrm{M}_{\mathrm{w}}$ of 6.6 for the mainshock. The epicentre of the earthquake was at a distance of $24 \mathrm{~km}$ from the town of Doganbey in Seferihisar, and the focal depth of the earthquake is approximately $17 \mathrm{~km}$. By 3 November 2020, 1475 aftershocks were recorded following the mainshock. Figure 1 shows the

Subhamoy Bhattacharya

S.Bhattacharya@surrey.ac.uk

1 İzmir Katip Çelebi University, İzmir, Turkey

2 Izmir Institute of Technology, İzmir, Turkey

3 University of Surrey, Guildford, UK 


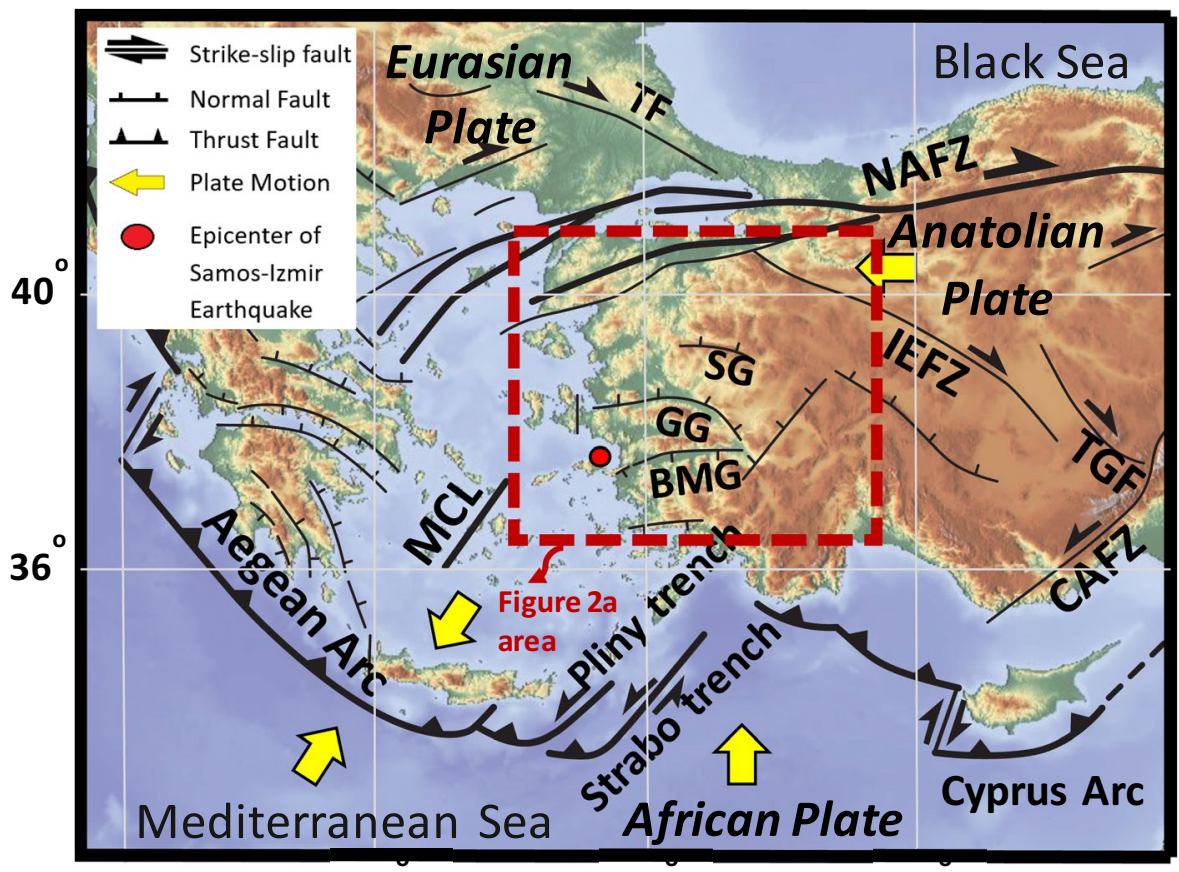

24

28

32

NAFZ: North Anatolian Fault Zone, CAFZ: Central Anatolian Fault Zone

TGF: Tuz Gölü Fault, IEFZ: İnönü-Eskişehir Fault Zone, SG: Simav Graben

AFZ: Akşehir Fault Zone, BMG: Büyük Menderes Graben, GG: Gediz Graben

TFZ: Thrace Fault Zone, MCL: Mid

- Cycladic Lineament

Fig. 1 Simplified Tectonic Map of Eastern Mediterranean ( modified from Uzel et al. 2013)

simplified tectonic map of the Eastern Mediterranean (Uzel et al. 2013). As seen in Fig. 1, the epicentre shown with a red circle on the figure is in the eastern Aegean Sea, which is a very seismically active area. Fault types observed in the area and plate motions are shown in the figure. Yellow arrows demonstrate directions of the plate motions. It is well known that numerous large earthquakes have occurred in this area in history and Fig. $2 \mathrm{~b}$ shows the locations of earthquakes, which have a moment magnitude larger than $3.0\left(\mathrm{M}_{\mathrm{w}}>3.0\right)$, occurred in the region since 1900 (https://deprem.afad.gov.tr/ddakatalogu). Figure 2a shows the locations of the epicentre of the 2020 Samos-Izmir earthquake and accelerometric stations. The values of Peak Ground Acceleration (PGA) recorded at these stations are also shown in the figure. The data associated with PGA values recorded at accelerometric stations and the locations of these stations are taken from the AFAD website (https:// deprem.afad.gov.tr/ddakatalogu).

The distribution of ground shaking in an earthquake in terms of peak ground acceleration or any other parameters provides very useful information to responding organizations beyond the earthquake magnitude and epicentre. These maps provide an immediate chance to determine what areas are subject to the highest intensities and potential impacts as well as those that experience only weak motions are highly possible to remain undamaged. They 

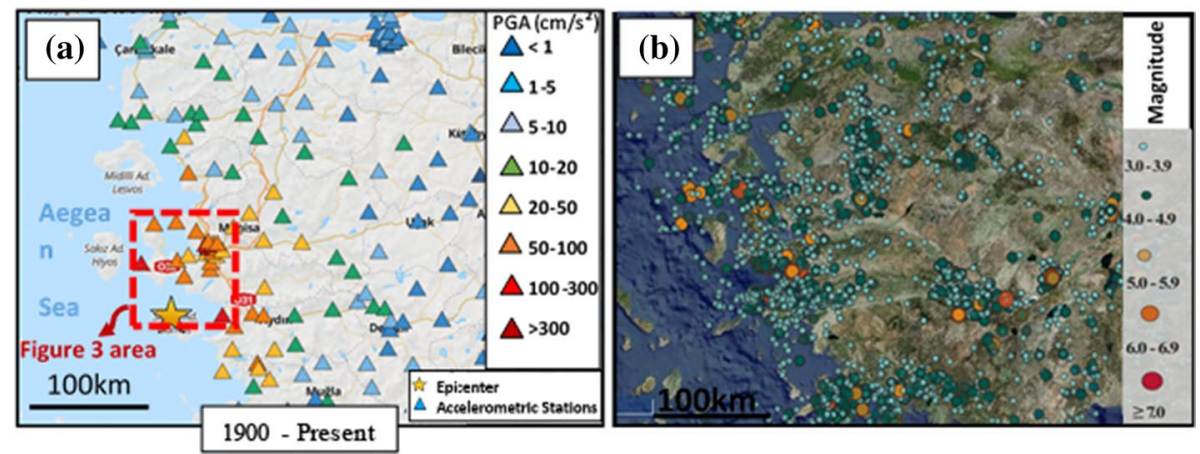

Fig. 2 a Location of the earthquake epicentre and accelerometric stations and PGA values measured at accelerometric stations (2020 Samos-Izmir Earthquake) (https://deprem.afad.gov.tr/ddakatalogu). b The map showing locations of earthquakes happened in the region since $1900\left(\mathrm{M}_{\mathrm{w}}>3.0\right)$ (https://deprem.afad. gov.tr/ddakatalogu)

also provide very significant information in supporting decision-making regarding damage assessment, aid to victims, mutual aid, and mobilization of resources (Shake Map manual).

Figures 3, 4, 5 and 6 demonstrate shake maps in terms of peak ground acceleration (PGA), peak ground velocity (PGV), $0.3 \mathrm{~s}$ spectral acceleration [SA (0.3)] and $1 \mathrm{~s}$ spectral acceleration [SA (1.0)] for 30 October $\mathrm{M}_{\mathrm{w}}$ 6.9 Samos-Izmir Earthquake. These shake maps were drawn by using strong ground motion data obtained from AFAD database on ArcGIS software. The contour lines with different colours show various magnitudes of PGA, PGV, SA (0.3) and SA (1.0) as seen in the figures. The unit of PGA, SA (0.3) and SA (1.0) is given as $\% \mathrm{~g}$ as seen in Figs. 3, 5 and 6 where $\mathrm{g}$ is gravitational acceleration. The unit of $\mathrm{PGV}$ is given as $\mathrm{cm} / \mathrm{s}$ as shown in Fig. 4. The red points on the maps illustrate the location of the area where many buildings experienced severe structural damages in Bayrakli and

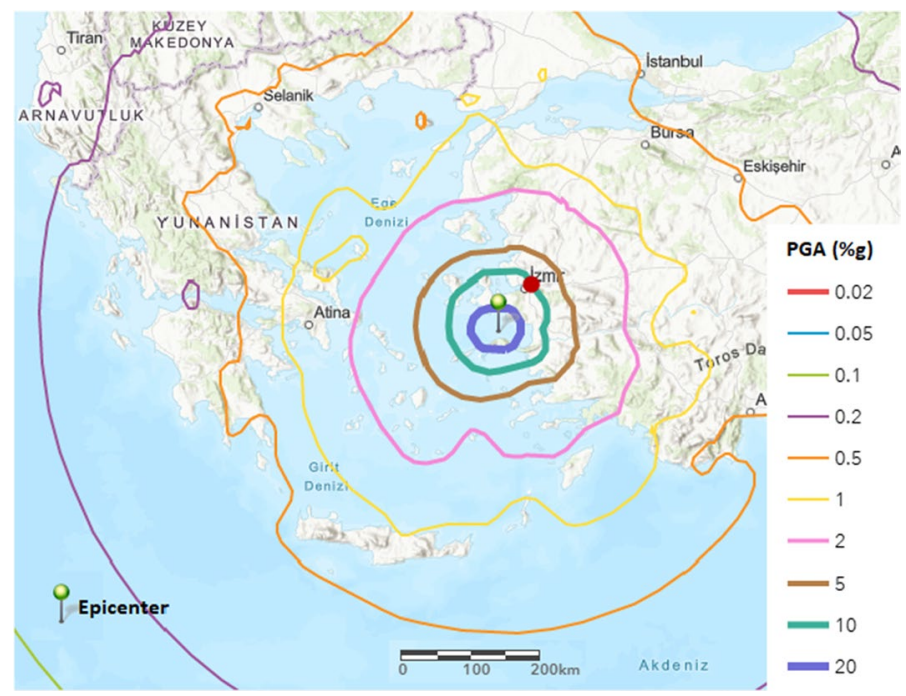

Fig. 3 a PGA shake map (\%g) for 30 October Mw 6.9 Samos-Izmir Earthquake 


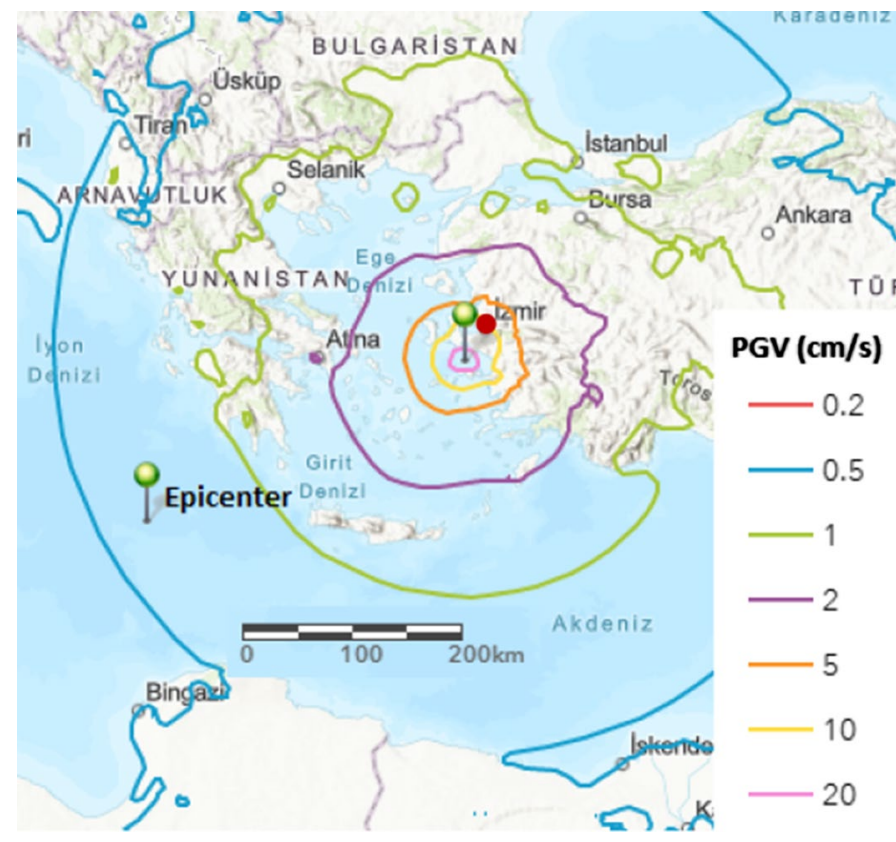

Fig. 4 PGV shake map (cm/s) for 30 October Mw 6.9 Samos-Izmir Earthquake

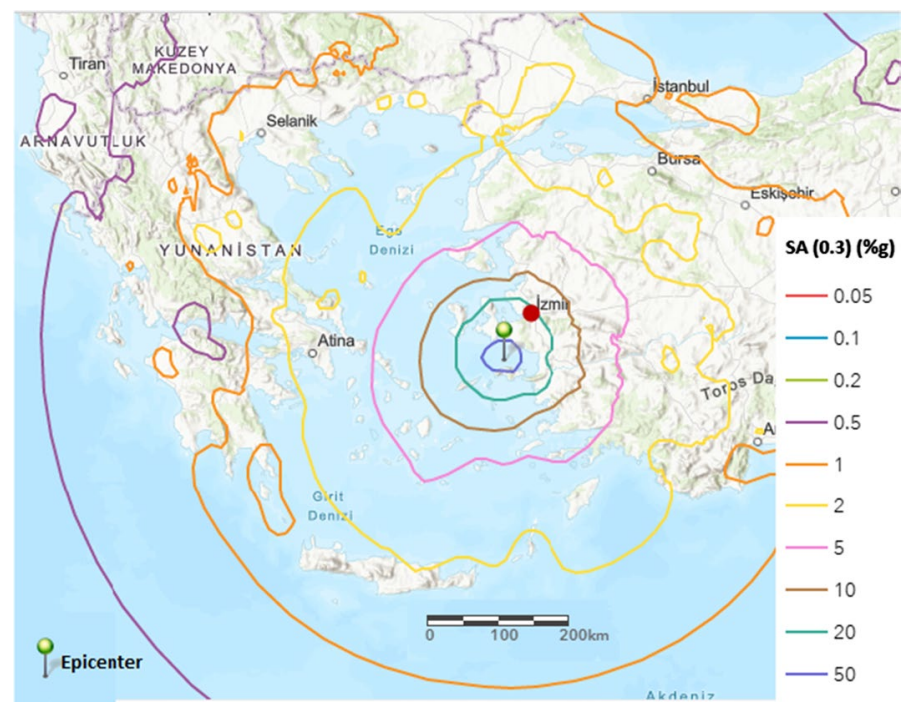

Fig. 5 SA (0.3) shake map (\%g) for 30 October Mw 6.9 Samos-Izmir Earthquake

Bornova region. The level of PGA at the location of the damaged area is around $10 \%$ of the gravitational acceleration $(0.1 \mathrm{~g})$ while the magnitude of PGV observed at the damaged area is around $10 \mathrm{~cm} / \mathrm{s}$ as seen in Figs. 3 and 4. The magnitude of SA (0.3) and SA (1.0) at the damaged area are $20 \%$ of the gravitational acceleration $(0.2 \mathrm{~g})$ as seen in Figs. 5 and 6. 


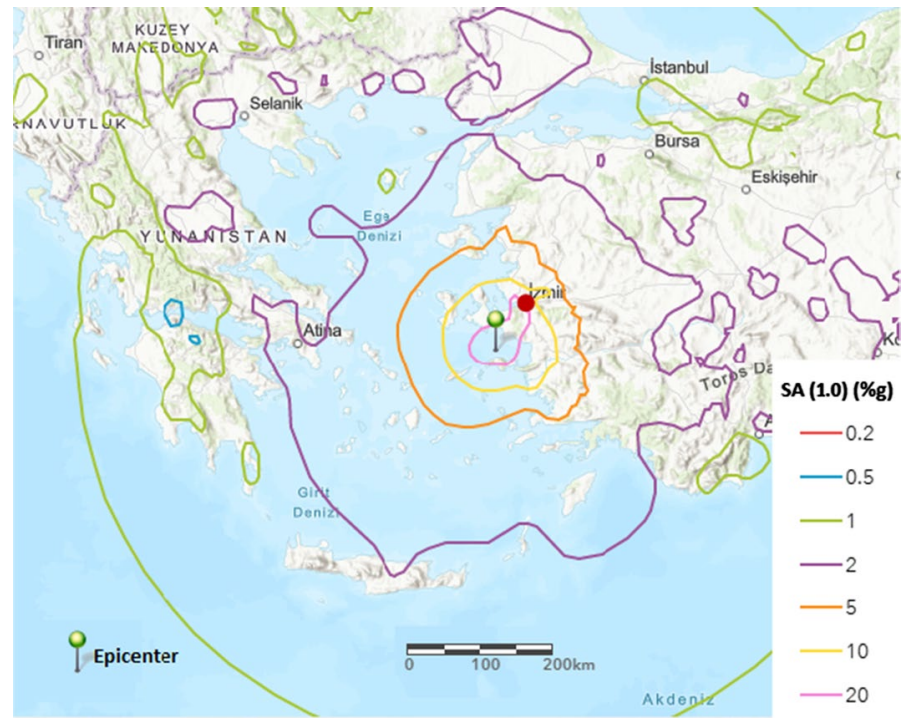

Fig. 6 SA (1.0) shake map (\%g) for 30 October Mw 6.9 Samos-Izmir Earthquake

The structural or geotechnical failures in past earthquakes have highlighted the shortcomings of construction practices and design methodologies. The limitations of engineering analysis, design and construction practices can be identified by post-earthquake reconnaissance investigations. These investigations also provide valuable insights on civil engineering problems observed in catastrophic events and issues/challenges that need to be addressed to minimise seismic damage due to future destructive earthquakes can be discovered by these investigations. This study discusses potential reasons for the severe structural damages observed in the west coast of Turkey in the 2020 Samos-Izmir Earthquake. Geology, seismicity, and tectonics of the damaged area are discussed in detail to understand local soil effects on the structural damage. Ground amplifications observed at the site where many buildings experience severe structural damages are also presented. Normalized response spectra for stations in the proximity of the damaged area are also compared with the corresponding ones for the 1975 and 2018 Turkish Earthquake Codes (TEC 1975 and 2018). The results presented in the study can provide better understanding of designing earthquake-resistant structures considering local soil effects and valuable insight on limitations of design methodologies and construction practices.

\section{Strong ground motion}

As shown in Fig. 2a, values of Peak Ground Accelerations (PGA) were recorded at more than 100 stations during the earthquake. By examining acceleration time history records, the stations where the largest five PGA values were recorded in the North-South (NS) direction and in the East-West (EW) direction were determined as follows: (1) the station located in the district of Bayrakli (station number: 3513), (2) the station located in the district of Karsiyaka (station number:3519), (3) the station located in the district of Mavisehir (station number:3521), (4) the station located in the district of Cesme (station number: 
3528) and (5) the station located in the district of Kusadasi (station number: 0905). Strong motion data of the station with number of 3536 located in the district of Seferihisar, which is the closest station to the epicentre on the land of Turkey, are also included in this study, and the locations of these six stations are shown in Fig. 7. The epicentre of the earthquake is shown with a yellow star and the damaged area where many buildings experienced severe damages is shown with a red dashed rectangle as seen in the figure. Acceleration time, velocity time and displacement time histories recorded at these accelerometric stations are plotted in Fig. 8 for both EW and NS directions. The values of peak accelerations, peak velocities and peak displacements are also noted on the graphs in Fig. 8. Discussing Fig. 7 and Fig. 8 together, it is seen that PGA values recorded in the NS direction ranges between 106 and $150 \mathrm{~cm} / \mathrm{sec}^{2}$ at stations 3513, 3519 and 3521, which are $69 \mathrm{~km}$, $69 \mathrm{~km}$ and $72 \mathrm{~km}$ away from the epicentre, respectively. On the other hand, the PGA value recorded at station 3536 , which is only $35 \mathrm{~km}$ away from the epicentre, is $50 \mathrm{~cm} / \mathrm{sec}^{2}$. It can be observed by comparing acceleration time histories recorded in the centre of Izmir and the town of Seferihisar that the values of PGA were amplified by around 2-3 times in the city centre of Izmir, where these three stations (3513, 3519 and 3521) are located. The ground motion amplification at these locations occurred since deep alluvial basin and delta deposits exist in the northern part of Izmir city centre and the north and northeast of Izmir Bay. The ground motion amplification in the region of Bayrakli where many buildings collapsed, or experienced severe damages is specially discussed in following sections.

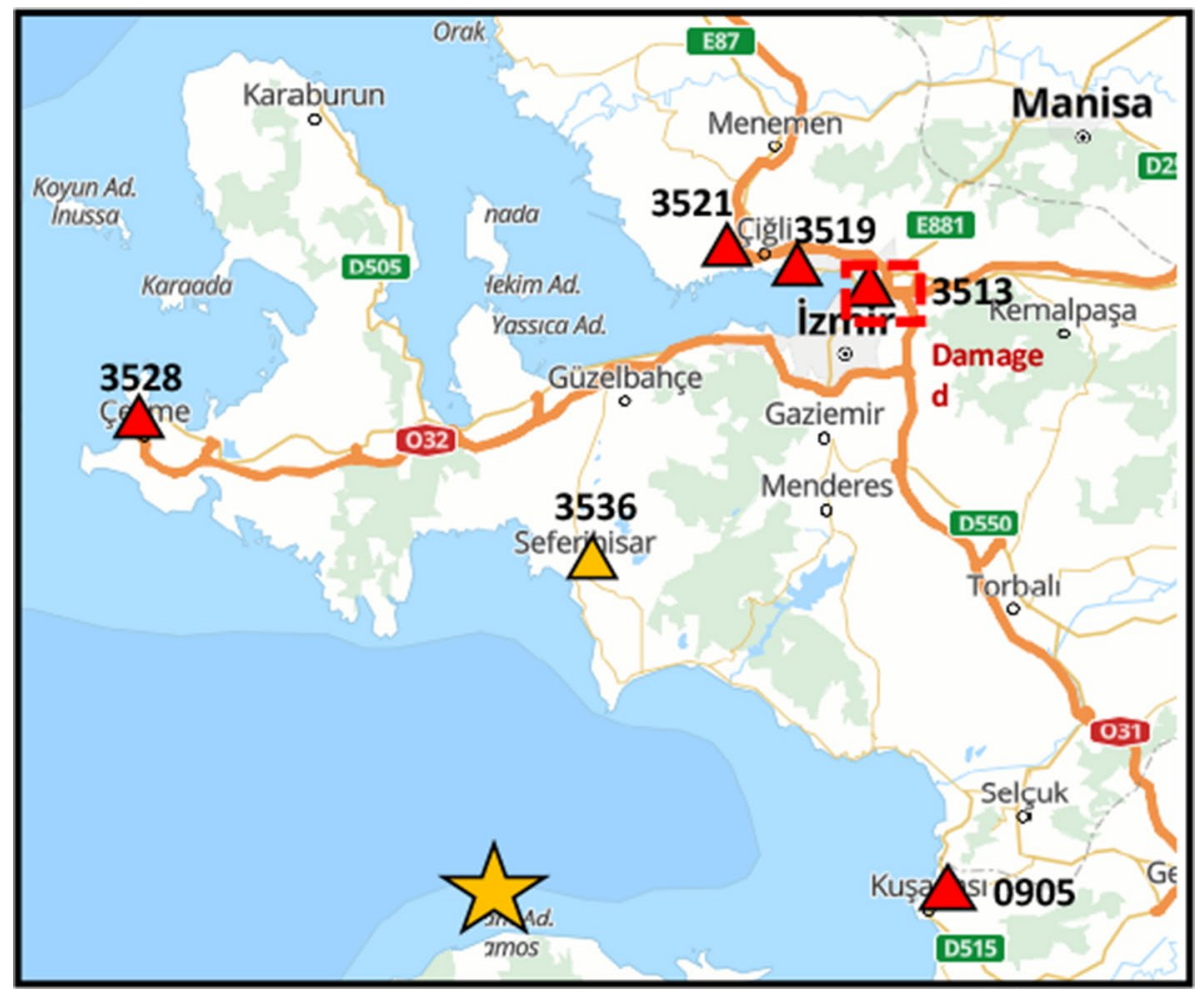

Fig. 7 A map showing the selected six accelerometric stations 

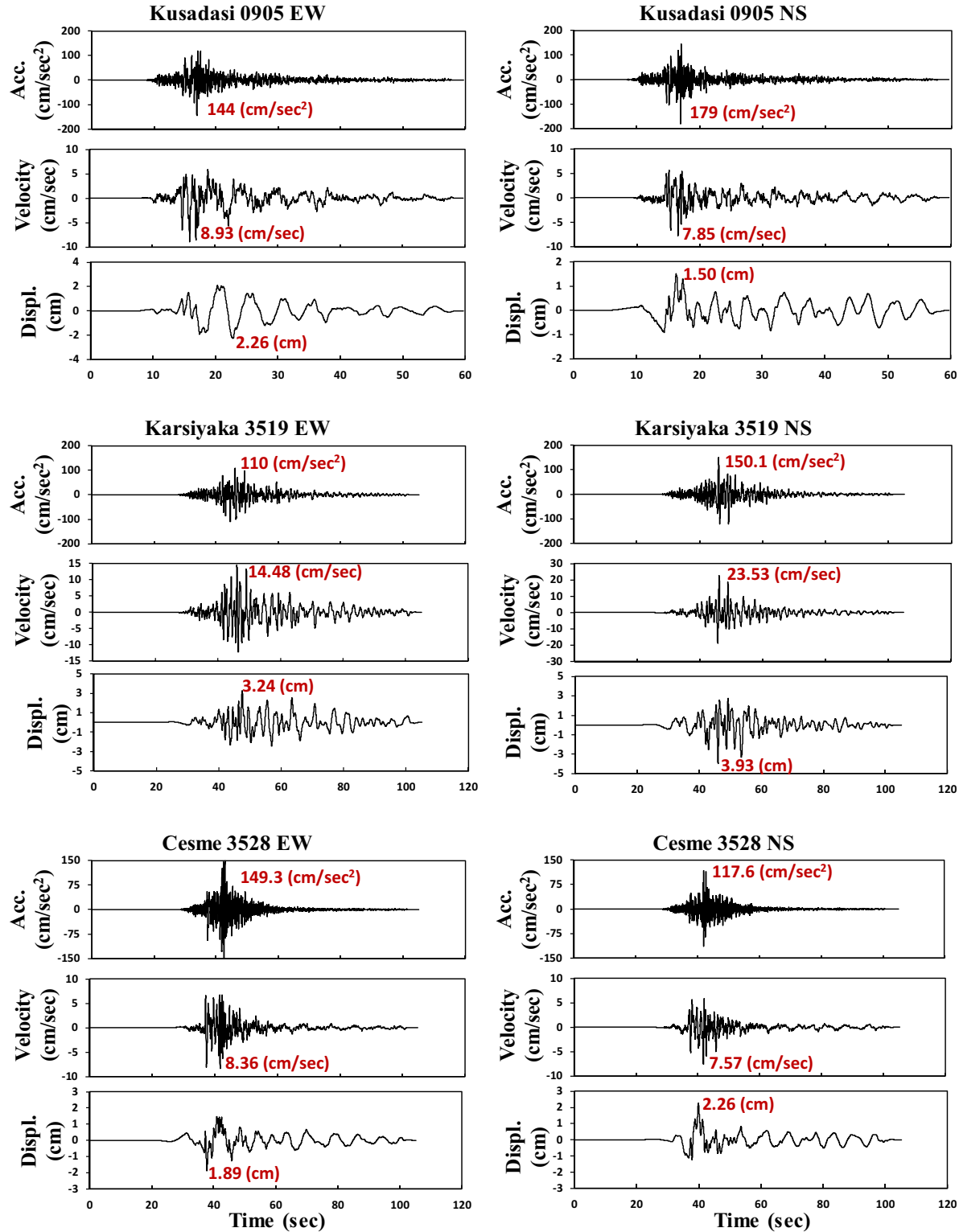

Fig. 8 PGA, PGV, PGD plots for six stations

The level of shaking to which engineering structures will be subjected is required to be estimated for the proper design of them. The level of shaking is often developed in terms of ground motion parameters such as Peak Ground Acceleration (PGA), and consequently, methods for predicting ground motion parameters are required. There are several predictive relationships available in the literature to estimate ground motion parameters. Predictive relationships to be used for estimating ground motion parameters that decrease with increasing distance are generally referred to as attenuation relationships. Many PGA 

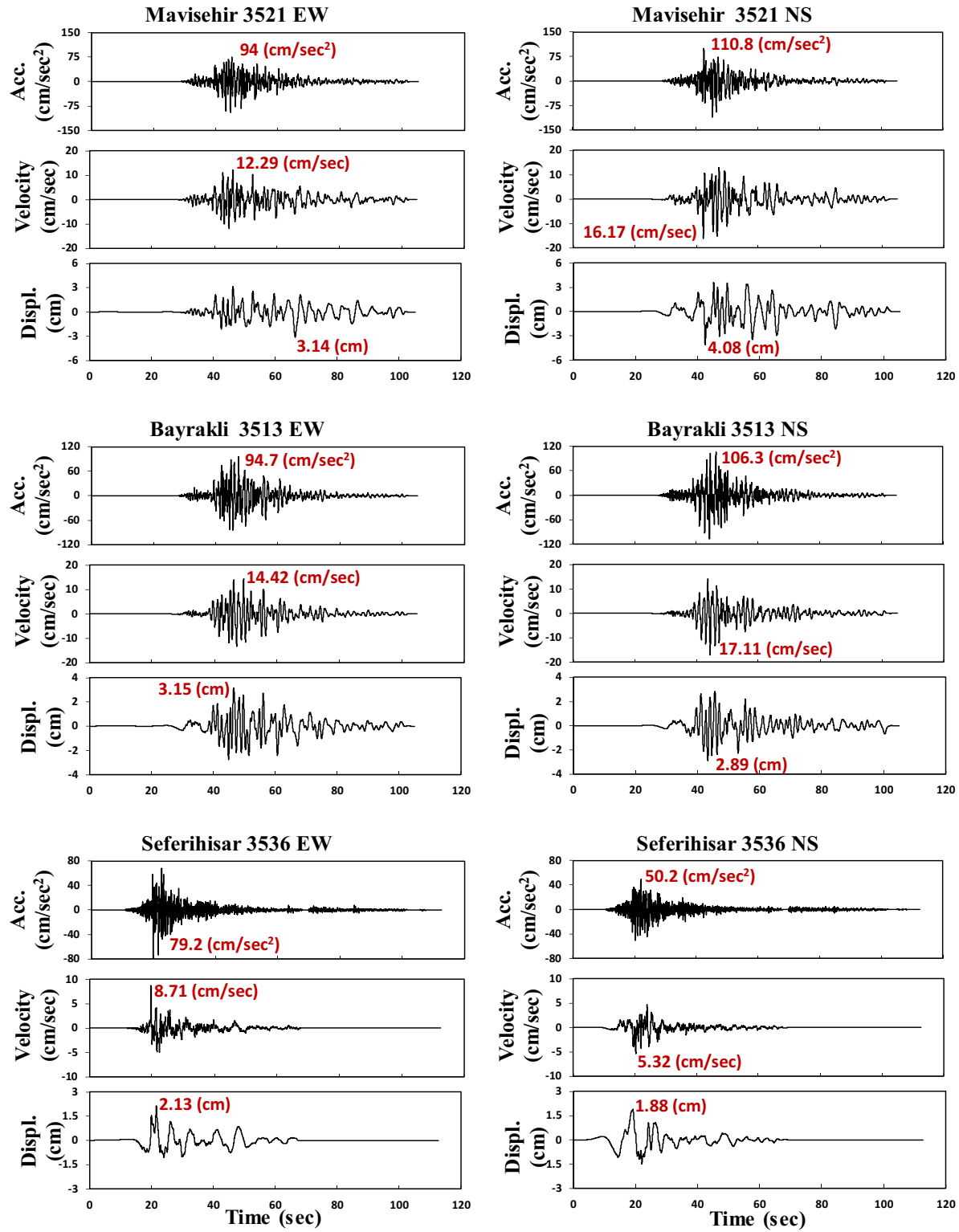

Fig. 8 (continued)

attenuation relationships were developed since PGA is the most widely used ground motion parameter. One of the important steps in carrying out both deterministic seismic hazard analysis (DSHA) and probabilistic seismic hazard analysis (PSHA) is obtaining attenuation relationships for ground motion parameters (e.g. PGA).

Figure 9 provides a comparison of peak ground accelerations (PGA) obtained by several accelerograms with the attenuation relationships proposed by several researchers (Campbell 1981; Boore et al. 1993; Campbell and Bozorgnia 1994). Red points show PGA values 


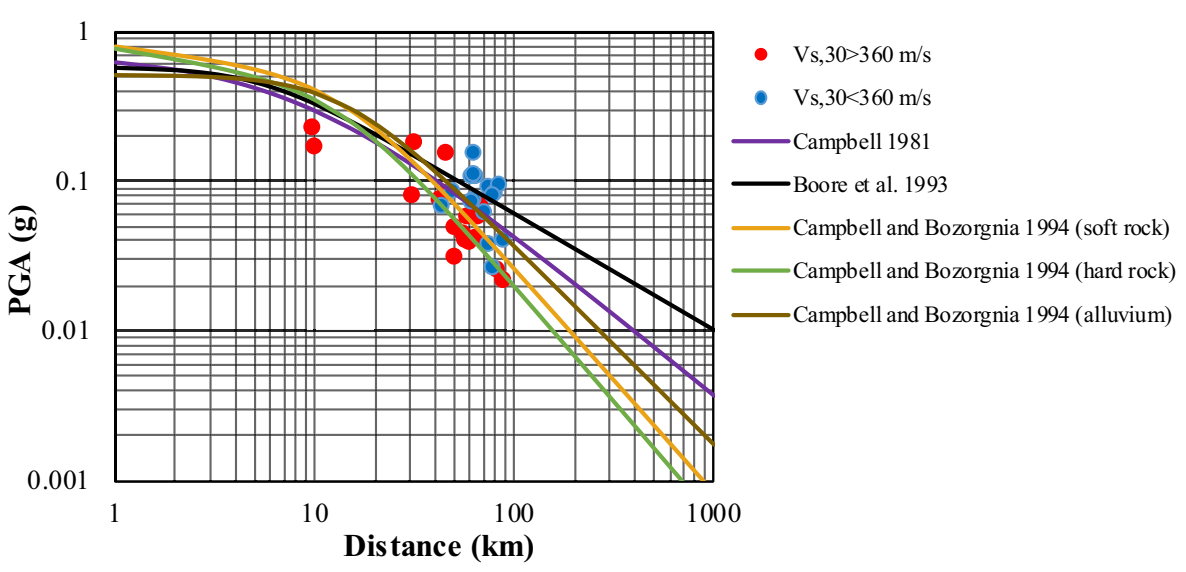

Fig. 9 Comparison of the recorded strong ground motion data for PGA with attenuation prediction models

recorded at accelerometric stations located where the average shear wave velocity of soils in the top $30 \mathrm{~m}$ depth $\left(\mathrm{V}_{\mathrm{s} 30}\right)$ is greater than $360 \mathrm{~m} / \mathrm{s}$ while blue points show PGA values recorded at accelerometric stations placed where the value of $V_{\mathrm{s} 30}$ is smaller than $360 \mathrm{~m} / \mathrm{s}$. Solid lines show PGA attenuation relationships suggested by Campbell (1981) [6], Boore et al. (1993) and Campbell and Bozorgnia (1994). The PGA attenuation relationships for soft rock, hard rock and alluvium soils are plotted by using equations proposed by Campbell and Bozorgnia (1994). The information on recorded strong ground motions plotted in the figure is taken from the stations within $100 \mathrm{~km}$ epicentral distance. All the attenuation relationships over predict PGA values observed in the earthquake at distances less than $10 \mathrm{~km}$. The acceleration data from the earthquake are generally bound by the minus and plus two standard deviation predictions at distances larger than $10 \mathrm{~km}$.

Basin effects have been observed in the past earthquakes including 1985 Hyogo-Ken Nanbu (Japan) Earthquake, 1995 Dinar (Turkey) Earthquake, 1999 Kocaeli (Turkey) Earthquake, 2011 Tohoku (Japan) Earthquake. Kawase (1996) expressed that ground motion was amplified by up to 3 times in 1985 Hyogo-Ken Nanbu Earthquake $\left(\mathrm{M}_{\mathrm{w}}=6.9\right)$ due to basin effects. Recorded values of peak ground accelerations (PGA) were $1200 \mathrm{~cm} / \mathrm{sec}^{2}$ at the station where a ground amplification was observed. Ground amplification was in the order of 4 in Tokyo Bay area in 2011 Tohoku Earthquake $\left(M_{w} 9.0\right)$ (Bhattacharya et al. 2011). The recorded values of PGA in 1999 Kocaeli Earthquake $\left(M_{w} 7.4\right)$ ranged between 163 and $790 \mathrm{~cm} / \mathrm{sec}^{2}$ as reported in the work of Sucuoglu (2000). The ground motion was amplified by $2-5$ times in Adapazari basin in the earthquake and mostly 5 to 8 storey reinforced concrete buildings were heavily damaged due to basin effects (Sucuoglu 2000). In 1995 Dinar Earthquake $\left(M_{w}=6.4\right)$, observed ground motion amplification was between 6 and 12 in Dinar basin. Mostly four to six storey buildings were heavily damaged in the earthquake due to basin effects (Yalcinkaya and Alptekin 2005). The structures placed on the relatively strong hard rock were lightly damaged or not damaged while the structures standing on the Dinar basin were severely damaged, confirming the destructive effect of ground amplification on structures (Durukal et al. 1998; Ansal et al. 2001). As seen in the past earthquakes, basin effects are responsible for severe damage to many buildings. In 2020 Samos-Izmir Earthquake $\left(\mathrm{M}_{\mathrm{w}}=6.9\right)$, many buildings located on Bornova basin were also heavily damaged. The observed ground amplification in the damaged area was 
between 2.5-3 and recorded PGA value in the area was $106.3 \mathrm{~cm} / \mathrm{sec}^{2}$. In this study, the effect of ground motion amplifications on the observed structural failures of buildings will be investigated in detail in next sections.

\section{Geology of the damage area}

In this section, the geology of the damaged area (the district of Bayrakli) where many buildings experienced severe damages are discussed in detail. Bayrakli is the region where many buildings experienced severe damages in the earthquake. Bayrakli is located on a very deep alluvial basin and delta deposits called Bornova Plain, which is bordered to the south and north by hills. Most of the district of Bayrakli is located on quaternary alluvial sediments of the basin. Figure 10a shows the three-dimensional topographic map of Bornova Plain and its surrounding. This map is modified from the work of Pamuk et al. (2019). The distribution of the average shear wave velocity in the top $30 \mathrm{~m}$ depth $\left(\mathrm{V}_{\mathrm{s} 30}\right)$ is also shown on the 3D map. The red dashed circle on the map shows the damaged area in Bayrakli. As seen in the figure, the values of $V_{s 30}$ range between 100 and $1400 \mathrm{~m} / \mathrm{s}$ on the map. The red point on the map shows the location of a borehole data obtained in Bayrakli. Soil profile observed from the borehole data is shown in Fig. 10b. The composition of the alluvium is spatially variable in vertical and horizontal directions. The soil profile consists of filling, silty sand, clay, silty clay, clayey sand, sandy gravel and gravelly clay layers.

\section{Strong ground motion in the damaged area}

Most of the heavy structural damages to the residential buildings occurred in the district of Bayrakli. The yellow balloons on the map in Fig. 11a show the locations of the collapsed and heavily damaged buildings in Bayrakli. The red lines in Fig. $11 \mathrm{a}$ and b show the area of the damaged buildings in the region. Three accelerometric stations exist in Bayrakli and they are numbered as 3513, 3514 and 3520 as seen in Fig. 11b. The average shear wave velocity in the top $30 \mathrm{~m}$ depth $\left(\mathrm{V}_{\mathrm{s} 30}\right)$ in the region of the stations are $196 \mathrm{~m} / \mathrm{s}, 836 \mathrm{~m} / \mathrm{s}$ and $875 \mathrm{~m} / \mathrm{s}$, respectively. The distance between the earthquake epicentre and \#3513 accelerometric station is $72 \mathrm{~km}$. The ground profile underlying the collapsed and heavily damaged buildings in Bayrakli is similar to that underlying the \#3513 station and is composed of alluvium deposit with thickness varying between 80 and $300 \mathrm{~m}$. The alluvium stratum includes layering of soft clay with an average plasticity index (PI) of 30 and silty sand. The groundwater level is close to the earth surface (1-3 m) (Gazi University 2020).

Ground motion records were analysed to examine the spectral content of the observed ground motions at the stations numbered 0905, 3519, 3528, 3521, 3536, 3513, 3514 and 3520. Figure $12 \mathrm{a}-\mathrm{d}$ plots the $5 \%$ damped response spectra for the mainshock. Figure $12 \mathrm{a}$ shows the graph of 5\% damped elastic acceleration response spectra for six accelerometric stations (mentioned in Sect. 2) in East-West (EW) direction while Fig. 12b shows the graph of 5\% damped elastic acceleration response spectra for six accelerometric stations in North-South (NS) direction. Figure 12c shows the 5\% damped elastic acceleration response spectra for three accelerometric stations located in the district of Bayrakli in EW direction while the graph of 5\% damped elastic acceleration response spectra for these three stations in NS direction is shown in Fig. 12d. As mentioned before, stations numbered 3514 and 3520 are located on strong soils like rocky soils (having $\mathrm{V}_{\mathrm{s} 30}>800 \mathrm{~m} / \mathrm{s}$ ) 
(a)

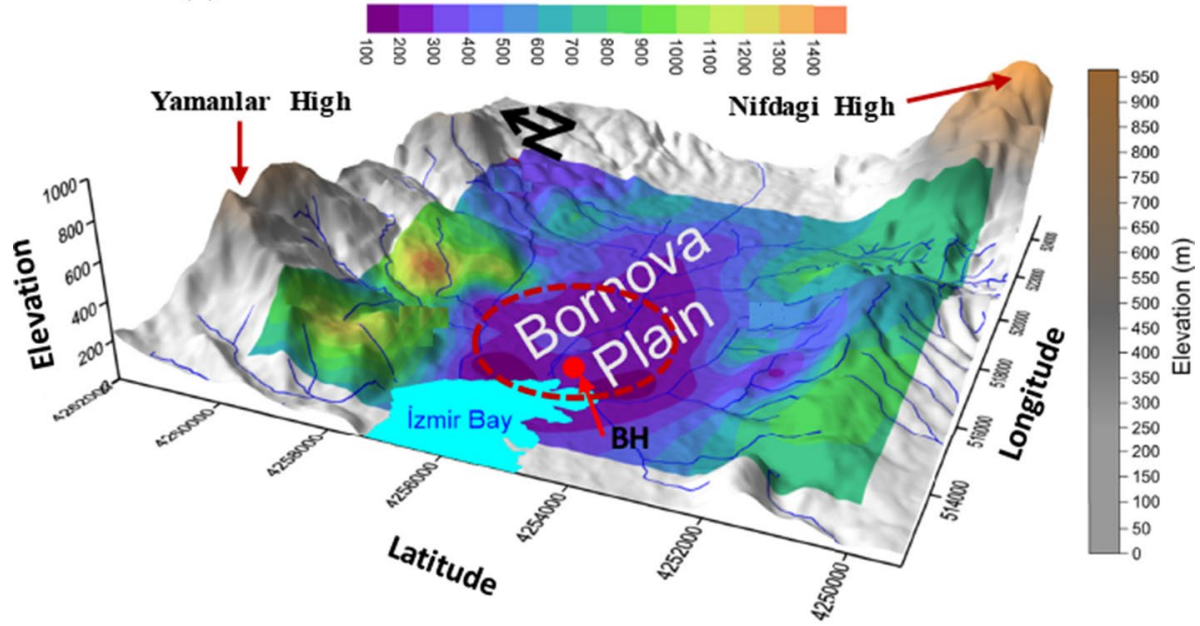

(b)

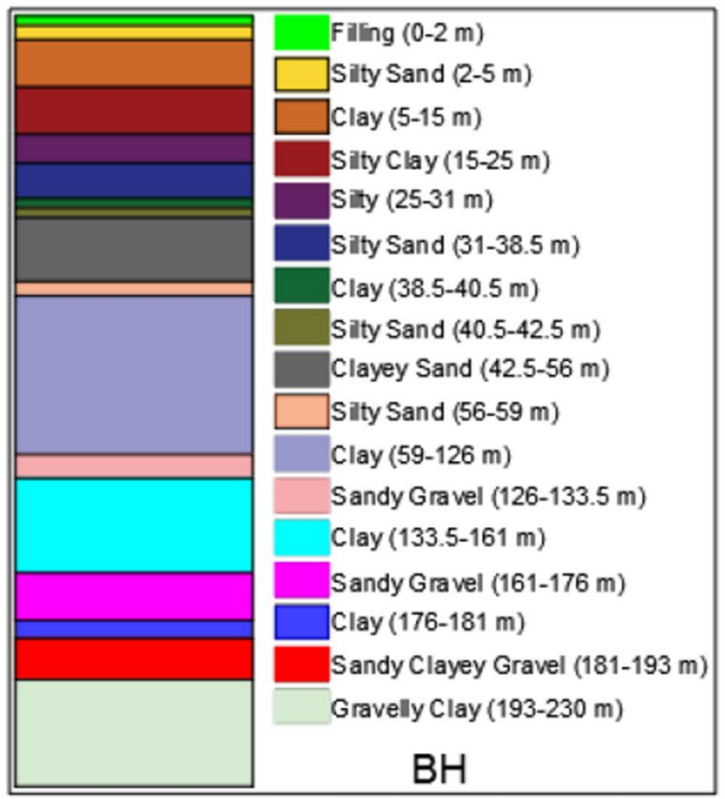

Fig. 10 a Three-dimensional (3D) topographic map of Bornova Plain and its surroundings showing distribution values of Vs30 (modified from Pamuk et al. 2019), b soil profile observed at the borehole location (modified from Pamuk et al. 2019)

while station numbered 3513 is placed on a weak soil profile. The results for the station numbered 3513 are presented by a solid red line while a blue line is used to present the results for the station numbered 3514. Finally, the results for the station numbered 3520 are presented by black solid lines. The comparison of the response spectra highlights: (i) horizontal ground motions are amplified in both EW and NS directions, (ii) ground motions 

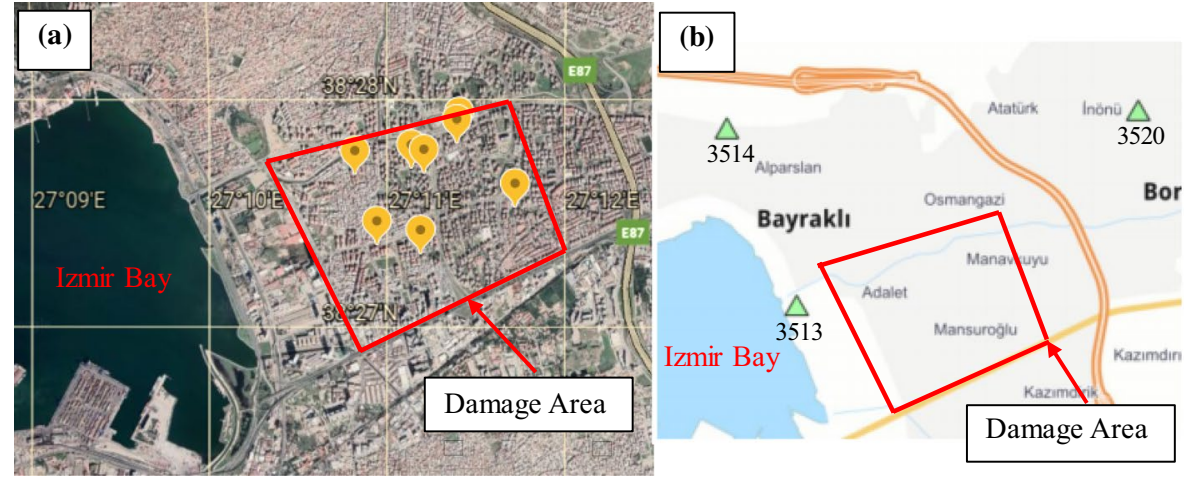

Fig. 11 a The map showing locations of collapsed and heavily damaged building in the region of Bayrakli and $\mathbf{b}$ a map showing the locations of accelerometric stations in the region of Bayrakli
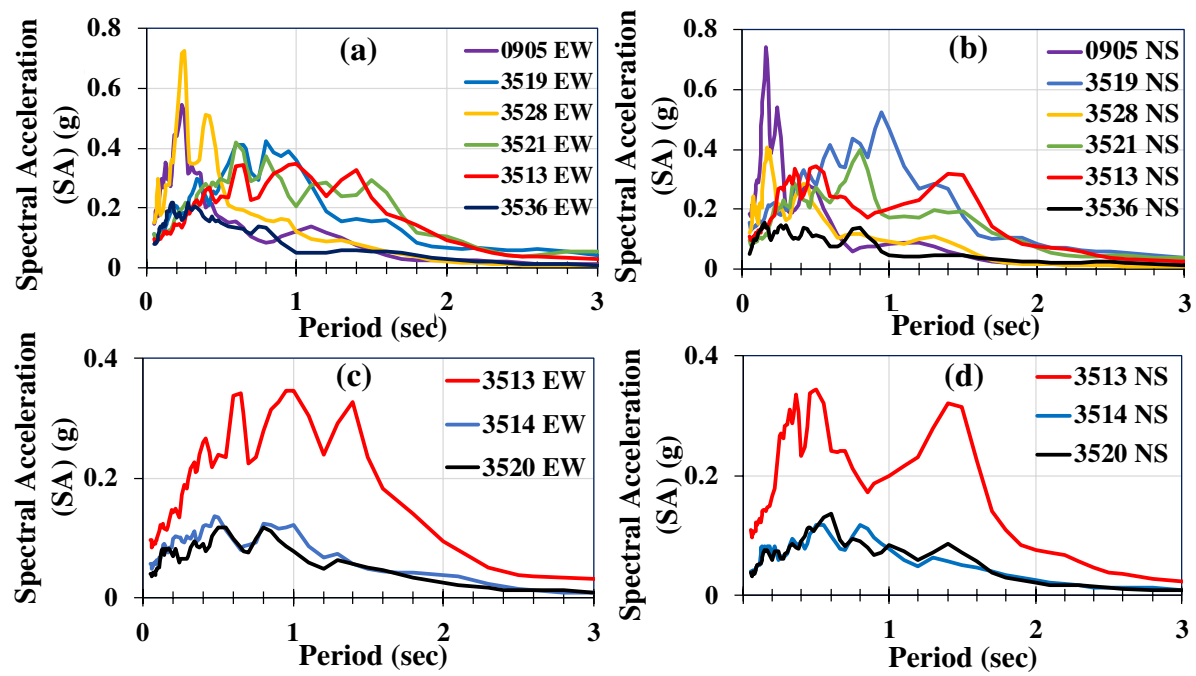

Fig. 12. 5\% damped elastic acceleration response spectra for records at selected stations $(0905,3519,3528$, 3521, 3513 and 3536): a East-West (EW) direction and b North-South (NS) direction, 5\% damped elastic acceleration response spectra for records at the stations in Bayrakli region (3513, 3514, 3520): c East-West (EW) direction and d North-South (NS) direction

are amplified by $2.5-3$ times between the periods of $0.4 \mathrm{~s}$ and $1.5 \mathrm{~s}$, (iii) amplitudes of the response spectra are at around $0.35 \mathrm{~g}$ for both EW and NS directions.

As the soil profile underlying station numbered 3513 best represents the soil profile in the damaged area, this ground motion is analysed in more details. The recorded data at this station are plotted with 5\% damped response spectra and are compared with design spectrums proposed in the 1975 and 2018 Turkish Earthquake Codes (TEC 1975 and 2018). Figure 13a and b shows acceleration time histories recorded at station numbered 3513 for NS and EW directions, respectively. Figure 14a compares the design code spectrums from the 1975 edition (TEC 1975) and the latest 2018 edition (TEC 2018) of the Turkish 


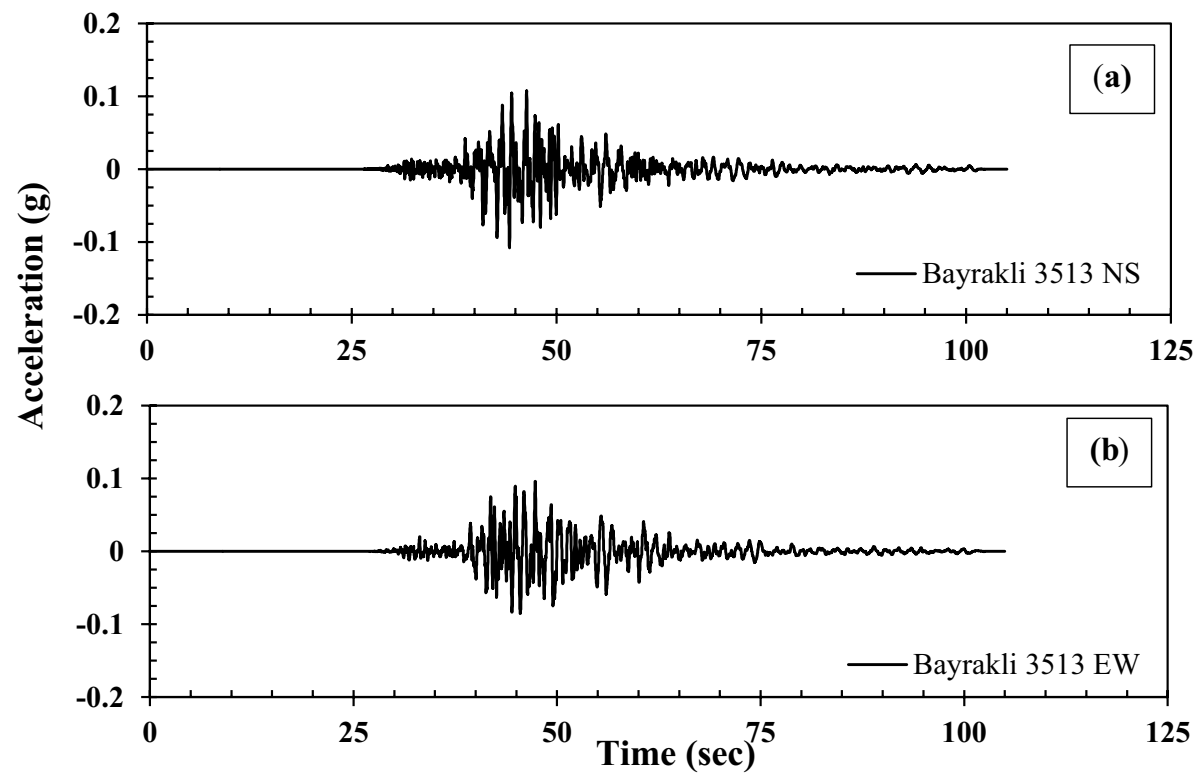

Fig. 13 \# 3513 accelerometric station: a Acceleration (g) vs. Time (sec) in NS direction, b Acceleration (g) vs. Time (sec) in EW direction
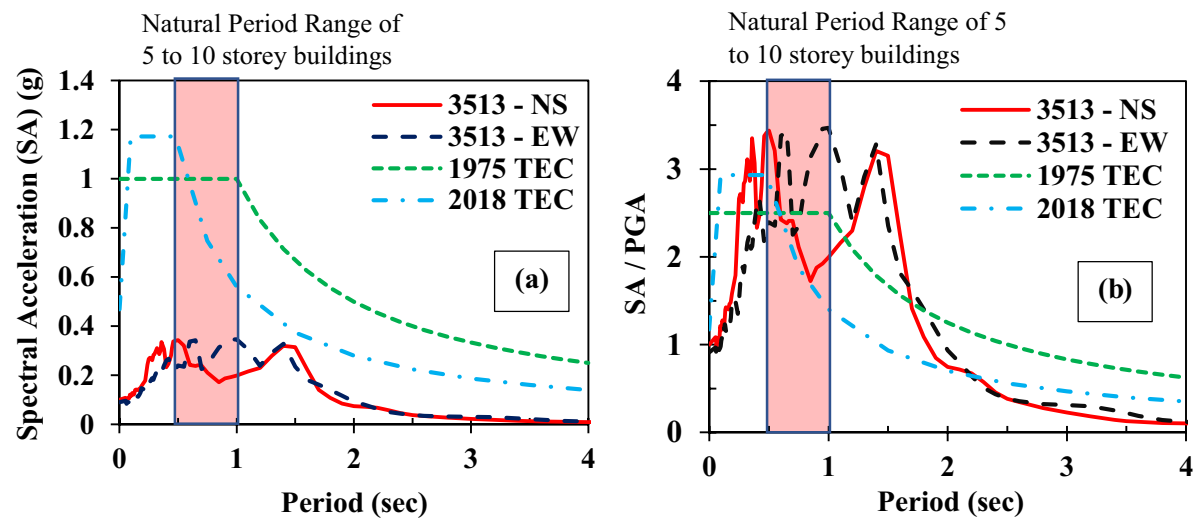

Fig. 14 a 5\% damped elastic acceleration response spectra for records at the station numbered 3513 within Bayrakli region with the corresponding ones for the 1975 Turkish Earthquake Code (TEC 1975) and the current version of Turkish code (TEC 2018) b Normalized acceleration response spectra for station 3513 within Bayrakli region with the corresponding ones for the 1975 Turkish Earthquake Code (TEC 1975) and the current version of Turkish Earthquake Code (TEC 2018)

Earthquake Code with 5\% damped elastic acceleration response spectra for records at the station numbered 3513 within Bayrakli region for NS and EW directions. The 1975 Turkish Earthquake Code (TEC 1975) is included in the graph as the heavily damaged buildings were designed and built by considering this earthquake code. The soil type encountered at the site is classed as IV b in the 1975 Turkish Earthquake Code. As mentioned, the latest 
2018 version of the code (TEC 2018) is also included in the graph where the soil type is assumed as ZD (similar to Class C soil in Eurocode 8 (EN 1998-1 2004) and design earthquake of DD2 (Return Period of 475 years or $10 \%$ chance of exceedance in 50 years). It is important to note that the spectral ordinates of recorded horizontal ground motions (3513 NS and $3513 \mathrm{EW}$ ) are below the ordinates elastic code spectrums proposed in 1975 and 2018 (TEC 1975; 2018). This observation is inconsistent with the extent and the degree of structural damage reported. Thus, severe structural damage may have been occurred due to other factors such as poor construction quality, non-compliance with legislation and modification of the structural system. These factors will be discussed in detail in Sect. 5.

Normalized response spectra are also used to make a straightforward comparison of spectral accelerations between codes and records (Pitilakis et al. 2013). Pitilakis et al. (2013) proposed normalized response spectra for the soil classes of the newly proposed classification system. Normalized design code spectra (SA / PGA) for 1975 and 2018 Turkish Earthquake Code are calculated by using the methodology proposed in the study of Pitilakis et al. (2013). 5\%-damped elastic response spectra of the records at the station numbered 3513 for East-West (EW) and North-South (NS) directions are also normalized by Peak Ground Acceleration (PGA). Figure 14b compares normalized acceleration response spectra for station numbered 3513 located in Bayrakli region and 1975 Turkish Earthquake Code (TEC 1975) and the current version of Turkish Earthquake Code (TEC 2018). It is obvious that normalized spectra for the recordings of the station numbered 3513 are well above the normalized design code spectra over a large interval of structural periods between 0.3 and $1.8 \mathrm{~s}$. This has highlighted inadequacy of design code spectra to consider soil amplification effects mobilized in specific geological structure of Bayrakli region under the Samos-Izmir Earthquake.

\section{Damage to the residential buildings}

Many residential buildings in the district of Bayrakli were heavily damaged and collapsed due to the 2020 Samos Earthquake. The damaged buildings in the region were 5 to 10 storey buildings and were older than 30 years. It can be assumed that the heavily damaged buildings were designed and constructed following the 1975 Turkish Earthquake Code (TEC 1975). The patterns of building damages are pancake collapse (total collapse) and ground floor failure (partial collapse) as seen in Fig. 15a and b. A similar failure of pancake collapse was also observed in the 1999 Kocaeli (Turkey) Earthquake and the 2011 Van (Turkey) Earthquake reported by Erdik (2000), EEFIT (2003) and Erdik et al. (2012). It was noted that there are many buildings with no significant structural damage in the neighbour of heavily damaged buildings. However, some cracks were noted in the nonstructural walls (Fig. 16a and b).

Calculations and measurements in the field showed that ground motion amplification is around 2.5-3 in the damaged area. Even though the ground motion was amplified by $2.5-3$, ordinates of $\% 5$-damped elastic acceleration response spectra for records at the station numbered 3513 are below the ordinates of design code spectra suggested in the 1975, 2018 Turkish Earthquake Codes (TEC 1975, 2018). However, the ordinates of normalized spectra for the recordings of the station in Bayrakli (3513) exceeded the ordinates of normalized design code spectra over a large interval of structural periods (between 0.3 and $1.8 \mathrm{~s}$ ). Considering Fig. 14a and slightly damaged or undamaged buildings in the damaged area which were designed and constructed using 1975 Turkish 

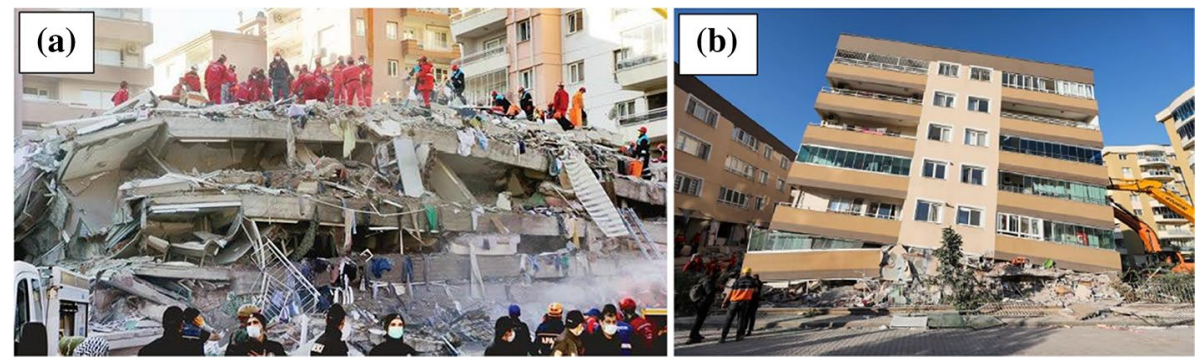

Fig. 15 a Pancake collapse, b Ground floor failure (https://www.aa.com.tr/tr/pg/foto-galeri/izmir-dedeprem/0)

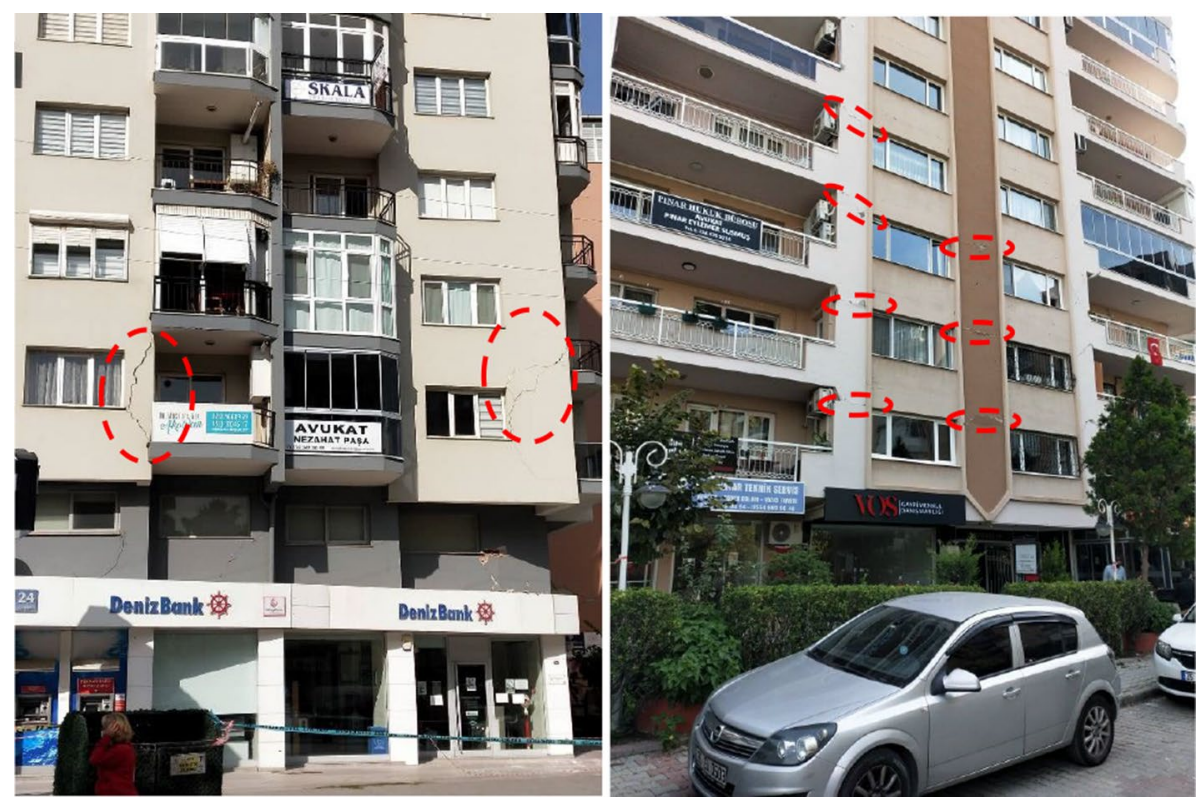

Fig. 16 Cracks in the non-structural walls due to the earthquake (wall cracks are shown with red dashed circles)

Earthquake Code, it may be concluded that there must be various other reasons for the damage observed in the residential buildings. The concrete quality in collapsed structures is reported to be very poor. It was noted that in some cases, there were no lateral reinforcement binders and poor ductility detailing of the beam-column connections. The spacing of lateral reinforcements in the beams and columns were large. Ground floor failures in the buildings developed due to the occurrence of the soft storey i.e. weak column on the ground floors. Ground floors are often used as offices and shops for which architectural renovation were made on the ground floors which often caused removal/ reduction of columns causing irregular load transfer. In summary, poor concrete quality, poor reinforcement, weak column-strong beam and soft storey problems may have contributed to the severe damages to the residential buildings. 


\section{Tsunami effects in Seferihisar}

The earthquake caused a tsunami which damaged some structures on the shore between the town of Akarca and Sigacik. The wave generated was $2 \mathrm{~m}$ and it travelled approximately $800 \mathrm{~m}$ towards the land. The tsunami caused many damages such as floating piers were dragged, (ii) some of the boats in Sigacik port overturned and submerged, and (iii) many buildings, shops and cafes on the shore were damaged (Gazi University 2020 and Izmir Institute of Technology 2020). Various damages associated with the tsunami are shown in Fig. 17a-d.

\section{Concluding remarks}

Observed damage patterns and earthquake characteristics from the 2020 Samos-Izmir earthquake are reported. In some location around $73 \mathrm{~km}$ from the epicentre, ground motions were amplified by 2.5 to 3 times and complete collapse of some buildings were noted. These collapsed buildings were built more than 30 years ago with improper design and poor structural detailing (beam-column connections poorly executed with lacking
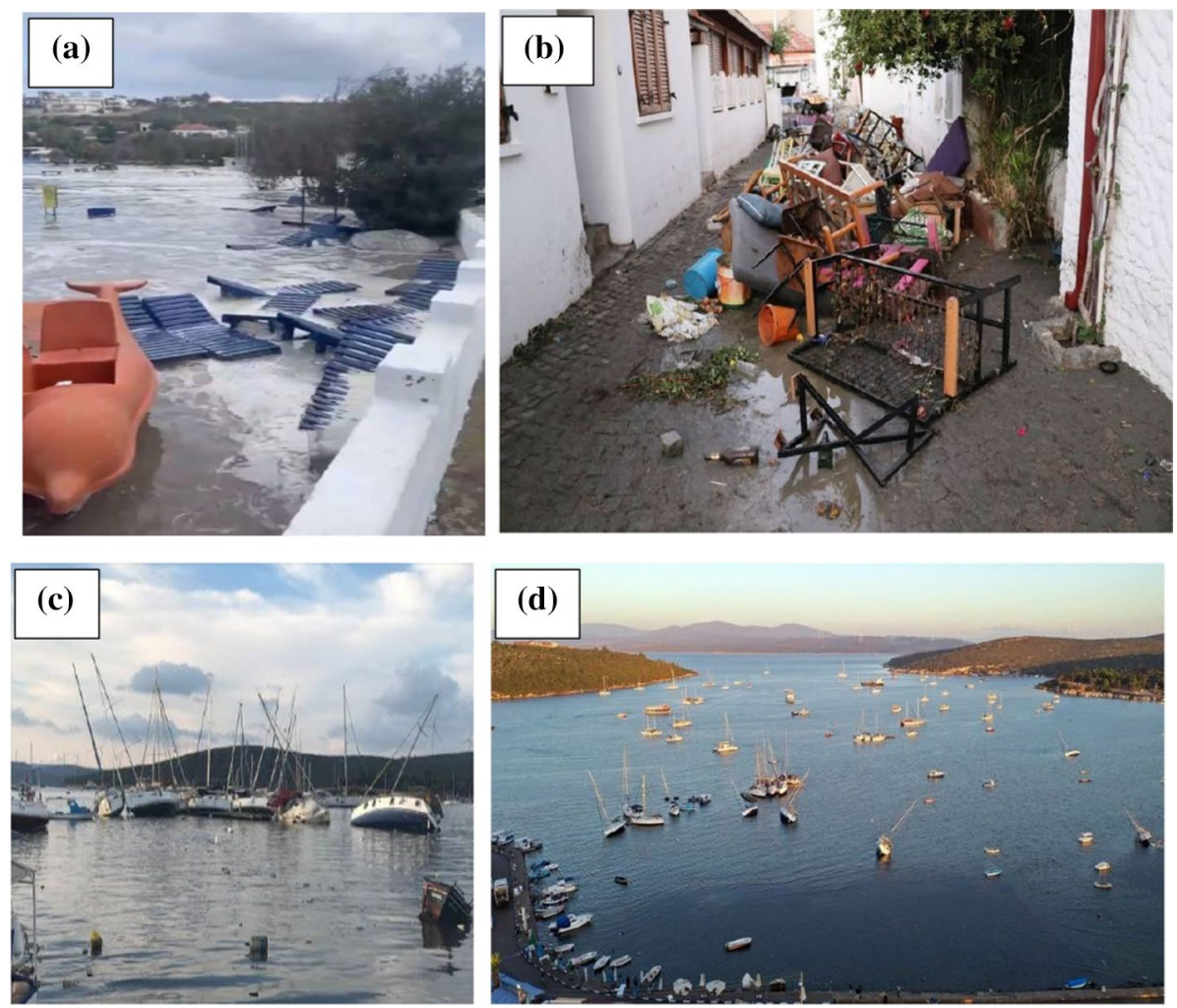

Fig. 17 a Sea level raised at a beach in Sigacik, b many tables and chairs in cafes and shops were dragged, c many boats overturned and submerged in the port of Sigacik, $\mathbf{d}$ a photograph showing the port of Sigacik (https://www.aa.com.tr/tr/pg/foto-galeri/izmir-de-deprem/0) 
confining reinforcements) and were most likely to be the cause of failure. It was noted that the ordinates of 5\%-damped elastic acceleration response spectra of the recordings in the damaged area did not exceed the ordinates of design code spectra proposed in 1975 and 2018 Turkish Earthquake Codes (TEC 1975; TEC 2018). Majority of the new buildings designed based on the latest codes of practice suffered only cracks in the non-structural part. Many parts of Turkey are seismic prone zone, and it is necessary to strengthen/retrofit the old buildings based on the latest understanding. The earthquake also triggered a tsunami in the Aegean Sea causing economic loss. Therefore, risk maps for the tsunami need to be developed for better preparedness.

Author contributions H.E.D and S.B. conceptualized and designed the study. H.E.D and M.K. obtained the data from AFAD database and reports that are used for the figures and graphs. H.E.D. wrote the first draft of the manuscript; all authors commented on this version of the manuscript. All authors read and approved the final manuscript.

Data availability The acceleration time histories used in the study were taken from the database of AFAD. The data are available at https://deprem.afad.gov.tr/ddakatalogu. The detailed information about the earthquake was taken from the reports published by Bogazici University, AFAD, Gazi University and Izmir Institute of Technology.

\section{Declarations}

Conflict of interests The authors declare that they have no conflict of interest.

Open Access This article is licensed under a Creative Commons Attribution 4.0 International License, which permits use, sharing, adaptation, distribution and reproduction in any medium or format, as long as you give appropriate credit to the original author(s) and the source, provide a link to the Creative Commons licence, and indicate if changes were made. The images or other third party material in this article are included in the article's Creative Commons licence, unless indicated otherwise in a credit line to the material. If material is not included in the article's Creative Commons licence and your intended use is not permitted by statutory regulation or exceeds the permitted use, you will need to obtain permission directly from the copyright holder. To view a copy of this licence, visit http://creativecommons.org/licenses/by/4.0/.

\section{References}

Afet ve Acil Durum Yonetimi Baskanligi (AFAD), Deprem Dairesi Baskanligi, 30 Ekim 2020 Ege Denizi, Seferihisar (Izmir) Aciklari (17.26 km) Mw 6.6 Depremine Iliskin On Degerlendirme Raporu, 2020

Ansal AM, Iyisan R, Gullu H (2001) Microtremor Measurements for the Microzonation of Dinar, Pure Appl. Geophys 158:2525-2541

Bhattacharya S, Hyodo M, Goda K, Tazoh T, Taylor CA (2011) Liquefaction of soil in the Tokya Bay area from the 2011 Tohoku (Japan) earthquake. Soil Dyn Earthq Eng 31:1618-1628

Bogazici Universitesi Kandilli Rasathanesi ve Deprem Arastirma Enstitusu Bolgesel Deprem-Tsunami Izleme ve Degerlendirme Merkezi, 30 Ekim 2020 Ege Denizi Depremi Basin Bulteni, October 2020

Boore DM, Joyner WB and Fumal TE (1993). Estimation of response spectra and peak accelerations from western North America earthquakes: an interim report, Open-File-Report 93-509, U.S. Geological Survey, Reston, Virginia, 72

Campbell (1981) Near-source attenuation of peak horizontal acceleration. Bullet Seismolo Soc Am 71(6):2039-2070

Near-source attenuation of peak horizontal acceleration from worldwide accelerograms recorded from 1957 to 1993, Proceedings, Fifth U.S. National Conference on Earthquake Engineering, Earthquake Engineering Research Institute, Berkeley, California, (pp. 283-292)

Durukal E, Erdik M, Avci J, Yuzugullu O, Alpay Y, Avar B, Zulfikar V, Biro T, Mert A (1998) Analysis of the Strong Motion Data of the 1995 Dinar, Turkey Earthquake, Soil Dyn. Earthq Engin 17:557-578 
EEFIT (2003). The Kocaeli, Turkey Earthquake of 17 August 1999

EN 1998-1 (2004) (English): Eurocode 8: Design of structures for earthquake resistance - Part 1: General rules, seismic actions and rules for buildings [Authority: The European Union Per Regulation 305/2011, Directive 98/34/EC, Directive 2004/18/EC]

Erdik M (2000). Report on 1999 Kocaeli and Duzce (Turkey) Earthquakes, DOI: https://doi.org/10.1142/ 9789812811707_0018

Erdik M, Kamer Y, Demircioğlu M, Sesetyan K (2012). 23 October 2011 Van (Turkey) earthquake. Nat Hazards 64, 651-665 (2012). https://doi.org/10.1007/s11069-012-0263-9

Gazi University (2020). Gazi Universitesi Deprem Muhendisligi Uygulama ve Arastirma Merkezi, Seferihisar Aciklari (Izmir) Depremi On Degerlendirme Raporu

https://deprem.afad.gov.tr/ddakatalogu

https://earthquake.usgs.gov/earthquakes/eventpage/us7000c7y0

https://www.aa.com.tr/tr/pg/foto-galeri/izmir-de-deprem/0

Izmir Institute of Technology (2020). 30 Ekim 2020 Seferihisar Depremi On Degerlendirme Raporu

Kawase H (1996) The cause of the damage belt in Kobe: "The basin-edge effect", constructive interference of the direct S-wave with the basin induced diffracted Rayleigh waves. Seism Res Lett 67:25-34

Pamuk E, Ozdag OC, Akgun M (2019) Soil characterization of Bornova Plain (Izmir, Turkey) and its surroundings using a combined survey of MASW and ReMi methods and Nakamura's (HVSR) technique. Bull Eng Geol Env 78(4):3023-3035

Pitilakis K, Riga E, Anastasiadis A (2013) New code site classification, amplification factors and normalized response spectra based on a worldwide ground-motion database. Bull Earthq Eng 11:925-966. https://doi.org/10.1007/s10518-013-9429-4

Sucuoglu H (2000). The 1999 Kocaeli and Duzce-Turkey Earthquakes, Middle East Technical University.

Turkish Earthquake Code (1975). Afet Bolgelerinde Yapilacak Yapilar Hakkinda Yonetmelik, 1975

Turkish Earthquake Code (2018). Turkiye Bina Deprem Yonetmeligi, Deprem Etkisi Altinda Binalarin Tasarimi icin Esaslar, 2018.

Uzel B, Sozbilir H, Ozkaymak C, Kaymakci N, Langereis CG (2013) Structural evidence for strike-slip deformation in the İzmir-Balıkesir Transfer Zone and consequences for late Cenozoic evolution of western Anatolia (Turkey). J Geodyn 65:94-116

Yalcinkaya E, Alptekin O (2005) Contributions of Basin-edge-induced Surface Waves to Site Effect in the Dinar Basin Southwestern Turkey. Pure Appl Geophy 162:931-950. https://doi.org/10.1007/ s00024-004-2649-4

Publisher's Note Springer Nature remains neutral with regard to jurisdictional claims in published maps and institutional affiliations. 